\title{
WELFARE IMPACT OF HIGH-NUTRIENT FOODS' PRICE INCREASE ON INDONESIAN HOUSEHOLDS: IS THERE A ROLE FOR OWN-FARM PRODUCTION?
}

\author{
Rodhiah Umaroh $^{{ }^{*} \text {, Evita Hanie Pangaribowo }}{ }^{2}$ \\ ${ }^{1}$ Faculty of Economics and Business, Universitas Gadjah Mada, Yogyakarta, 55281, Indonesia \\ ${ }^{2}$ Faculty of Geography, Universitas Gadjah Mada, Yogyakarta, 55281, Indonesia
}

\begin{tabular}{|c|c|}
\hline ABSTRACT & ARTICLE INFO \\
\hline $\begin{array}{l}\text { Introduction/Main Objectives: Significant price increases in food items } \\
\text { and uncertainty in the market probably have a severe impact on society, } \\
\text { and especially on low-income households. Background Problems: The } \\
\text { increases in food prices could have a large impact on the economy and } \\
\text { specifically on households. Thus, this study was conducted to investigate } \\
\text { what the demand for food, specifically high-nutrient food items, and the } \\
\text { impact on welfare are like in Indonesian households when food prices } \\
\text { rise. Novelty: There is a great deal of empirical research into the impact } \\
\text { of food price changes on household welfare, however studies that have } \\
\text { focused on high-nutrient commodities, in particular on self-produced } \\
\text { food, are still limited. Many of the previous studies used cross-sectional } \\
\text { data for one period but this study used two-wave longitudinal data. } \\
\text { Research Methods: Using a large sample of data from the Indonesian } \\
\text { Family Life Survey (IFLS), this study employed the quadratic almost } \\
\text { ideal demand system (QUAIDS) to identify the demand pattern and } \\
\text { applied compensating variation (CV) to understand the impact of soaring } \\
\text { food prices on welfare changes. Findings/Results: Overall, the analysis } \\
\text { of the impact notes that when prices increase, all household groups } \\
\text { would experience welfare losses. The poorest households would } \\
\text { experience less of a welfare loss than the richest households, while a } \\
\text { larger welfare loss is suffered by households in Java and rural areas. } \\
\text { Conclusion: For the low-income households, having their own } \\
\text { productive farms could overcome any economic shocks threatening } \\
\text { them. Thus, the government should support small-scale farming through } \\
\text { such strategic policies as giving them assistance and training in how to } \\
\text { manage a small farm. }\end{array}$ & $\begin{array}{l}\text { Article history: } \\
\text { Received } 7 \text { October } 2019 \\
\text { Received in revised form } 2 \\
\text { January } 2020 \\
\text { Received in revised form } 3 \\
\text { February } 2020 \\
\text { Accepted } 5 \text { February } 2020 \\
\text { Keywords: } \\
\text { farm products, QUAIDS, } \\
\text { compensating variation, } \\
\text { welfare, food price } \\
\text { JEL Code: } \\
\text { C31, D11, Q11, Q12 }\end{array}$ \\
\hline
\end{tabular}

\footnotetext{
* Corresponding Author at Faculty of Economics and Business, Universitas Gadjah Mada, Jalan Socio Humaniora No. 1, Yogyakarta 55182, Indonesia.

E-mail address: dhiah.basuki@gmail.com, evitahp@ugm.ac.id
} 


\section{INTRODUCTION}

Indonesia's inflation rate has fluctuated remarkably since the 1997/1998 period when the global financial crisis occurred. The fluctuations in food prices made the greatest contribution (9.62\%) to the high inflation rate, followed by other commodities such as cigarettes, tobacco, prepared food, and beverages (7.27\%). These two rates are higher than the national average inflation rate of $6.22 \%$ (Badan Pusat Statistik, 2016). The data also show that the inflation rates of non-food commodities such as medical care, clothing, housing and electricity, education and recreation, and transportation and financial services are $4.61 \%, 5.44 \%, 5.03 \%, 5.25 \%$, and $3.89 \%$, respectively. This suggests that the price increase in food items is greater than that for non-food commodities (Allo et al., 2018).

Significant price increases in food commodities and uncertainty in the market probably have a severe impact on society and especially on low-income households. Household spending on other substantial needs such as education, health, and recreation would be limited due to a spike in the price of food (Akbari et al., 2013). Hence, it has become a pertinent issue to investigate consumers' food demands, and assess the changes on household welfare. This study focuses on the price changes in highnutrient food items, with particular attention being paid to dietary protein obtained from plant or animal sources. In fact, the consumption of high-nutrient food items in developing countries is still not great; most of the food items being consumed are still staple food items. The approximation is that the consumption of staple food is $20 \%-30 \%$ of the total food consumption (Agbola, 2000; Diehl et al., 2019; Haq et al., 2011; Korir et al., 2018). Meanwhile, in Indonesia, staple food items make up 19\%-36\% of total household food spending (Pangaribowo \& Tsegai, 2011; Widarjono, 2012).
There is much empirical research that discusses the impact of changes in the price of food on household welfare, however, studies focused on high-nutrient foods are still limited. A study of the effect of changes in the price of high-nutrition foods on household welfare can provide an insight into the level of food security in a country. This is quite important considering food security is not only concerned with the availability of food, but also with the distribution and quality of food. An increase in the price of high-nutrition foods should not interfere with the nutritional adequacy of food for household members, or in other words the decrease in consumption due to price increases will not be significant. This has been confirmed by several findings in developed countries (Abdulai, 2002; Kearney, 2010). In 2014-2016 there was an increase, of up to $20 \%$, in the price of meat from poultry and cattle which caused a decline in household purchasing power (Frandhika, 2015; Kementerian Perdagangan, 2016). The price of highly nutritious food is still considered expensive by Indonesian people and thus when the price soars; there would be a rapid decline in its consumption. Certainly, this condition does not help households, for even though the consumption of high-protein food such as beef, poultry, and fish has been growing it is still inadequate. The consumption of these food commodities in Indonesia is still far behind that of other ASEAN countries such as Singapore, Malaysia, and Thailand (Kementerian Perdagangan, 2016). However, people not only require a sufficient quantity of food but also take into account the quality of the food. Therefore, the government would usually act to make strategic policies to overcome the price increase.

Currently Indonesia has quite a large number of farmers, although they are increasingly being displaced due to industrialization. According to FAO (2017), 93\% of the total number of farmers fall into the category of owners of a small family 
farm. As the owners of small farms, they have a tendency to consume their own crops, as well as selling them. It is estimated that around $15 \%$ of the food that they consume is obtained from their own farms. According to research in developing countries, small-scale farming has supported efforts to improve household food security (Vu \& Glewwe, 2015; Wardhani, 2017). In the financial crisis of 2008, Nigerian households felt the severe effect of increasing food prices, but the effect was not as great for rural households as it was for those in urban areas, because the majority of the rural households had their own farms to help them deal with it (Sabo et al., 2018).

Much research into the impact of price increases on household welfare has been undertaken by many researchers in either developing or developed countries. However, a focused study into what the impact is like if households consume their own farm products, and specifically those that are high in nutrients, is still limited. Thus, this study is aimed at analyzing the effect of soaring high-nutrient food prices on welfare changes and evaluating whether the farmers' consumption of their own farm products had a role in causing this effect.

\section{LITERATURE REVIEW}

A number of studies have confirmed that the demand for high-nutrient food items is sensitive to price and expenditure changes. However, the magnitude of the effect varies between countries. In developing countries, high-nutrient foods are very sensitive to price and expenditure changes (Kumar et al., 2011; Le, 2008; Pangaribowo \& Tsegai, 2011). Meanwhile, in the context of developed countries, the magnitude is less than that in developing countries (Abdulai, 2002; Okrent \&Alston, 2011). The consumption of high-nutrient food could also represent the level of the countries' welfare. In developed countries, the consumption of high-nutrient foods, especially from animal sources, is higher and more stable than it is in developing countries. Changes in prices would not alter the demand a lot (Kearney, 2010). Several studies have also found similar results, when there is an increase in price due to some financial crisis, the greatest decline is seen in the demand for high-nutrient foods such as beef, poultry, and other types of meat (F.R \& Rahji, 2014; Fabiosa \& Jensen, 2002). This indicates that households shift their consumption to cheaper food, such as eggs or plant-based proteins, when food prices rise. Wardhani (2017) specifically analyzed the fooddemand pattern in relation to the consumption of self-produced food in Indonesian rural households, by using data from SUSENAS (Survei Sosial Ekonomi Nasional/National SocioEconomic Survey) and applying the LA/AIDS (Linear Approximated Almost Ideal Demand System) model. From the result it is found that the lower the household's income is, the higher the consumption of self-produced tubers and fruit is. In contrast, the consumption of eggs, milk, and other food items reduces. This shows that rural households still depend on their own farm products to meet their consumption needs.

To measure the magnitude of the welfare change, the previous literature suggests the use of the compensating variation (Akbari et al., 2013; Allo et al., 2018; Attanasio et al., 2013; Me-Nsope \& Staatz, 2016; Vu \& Glewwe, 2015). This compensating variation (CV) is the money metric which calculates the difference between the minimum money needed to reach the initial utility level at the new price level, and the initial total expenditure (Akbari et al., 2013). Research conducted by Attanasio et al. (2013) evaluated the welfare consequences of a food price spike in Mexico and found that higher food prices made the majority of households worse off, by 19\%. A similar result, found by Aftab et al., (2017) in South Asian countries, shows that 
a significant food price increase leads to a remarkable loss of income and purchasing power by households. Akbari et al., (2013) in their research also confirmed that when there is an increase in food prices, households experience a welfare loss and shift their consumption to lower calorific-value foods, and reduce their consumption of meat, dairy products, fruit, and vegetables. A more specific analysis conducted by Allo et al. (2018) considered the impact of increases in prices for both consumers and producers. The result suggests that the impact on welfare changes depends on demographic, geographic, and socioeconomic conditions. The households living in rural areas, outside of Java and Bali, especially those in eastern Indonesia which work in the agricultural sector, and are generally included in low-income household groups, experience a smaller welfare loss. This occurs because they have resources to help them cope with price increases. Weber (2015) analyzed the effect of rising prices on welfare and poverty changes in India and noted that a greater welfare loss is suffered by rural households than by urban households. The analysis by simulation has also found that an increase in food prices causes additional poverty by $4.69 \%$ and $2.19 \%$ in rural and urban households, respectively.

\section{METHOD, DATA, AND ANALYSIS}

\section{Data}

The data used in the study were panel data from the Indonesian Family Life Survey (IFLS) conducted by the RAND (Research and Development) organization. IFLS has the longest longitudinal data from socioeconomic and health surveys conducted in Indonesia. The sample represents $83 \%$ of the Indonesian population in 13 provinces in 1993. The survey collected data on individuals, families, households, and communities, and the use of public facilities such as educational and health services. This study used the data from the two latest waves of the IFLS survey, namely the fourth wave of IFLS in 2007 and its fifth wave in 2014. Approximately 50,000 individuals and 15,000 households were interviewed during these waves.

In order to analyze food consumption's demand using the demand system, the data on food consumption's expenditure were utilized. IFLS collected data on consumption expenditure for the purchase of products from the market and from people's own production. The study then specifically used the data on the consumption of food from people's own production. The said data provided were at the household level, because IFLS does not provide individual-level data for this type of information. Thus, it is assumed that all the household members have an equal share of consumption. The food that was analyzed in this study was a high-nutrient food bundle with a specifically high-protein content, consisting of bean, tofu and tempe groups as the proxies for plant protein and meat, poultry, fish, and milk groups representing animal protein. Those food types were chosen because they were considered to have a higher protein content than other foods. The details of the food types are presented in Table 1.

Table 1. Classification of Food Groups

\begin{tabular}{|c|c|}
\hline Food Groups & Details \\
\hline Beans & $\begin{array}{l}\text { peanuts, green beans, kidney } \\
\text { beans, soybeans, and the like. }\end{array}$ \\
\hline Tofu and Tempe & tofu, tempe, and oncom \\
\hline Meat & $\begin{array}{l}\text { beef, lamb, buffalo meat, and the } \\
\text { like. }\end{array}$ \\
\hline Poultry & chicken, duck, and the like \\
\hline Fish & $\begin{array}{l}\text { fresh fish, shellfish, shrimp, } \\
\text { squid, and the like as well as }\end{array}$ \\
\hline Milk & $\begin{array}{l}\text { salted fish and smoked fish } \\
\text { fresh milk, canned milk, } \\
\text { powdered milk, and the like }\end{array}$ \\
\hline
\end{tabular}

Source: IFLS Data (Processed) 
In addition, to complete the demand system, the study needed information about the price of food. Fortunately, IFLS provides data of the market price in the large traditional markets in each enumeration area. Table 2 summarizes the average market price for each food group. The study also considered household and community characteristics to capture their behavior. After the data's cleaning process, 3264 households were included in the study.

Table 2.Market Price (Rupiahs)

\begin{tabular}{lccc}
\hline \multicolumn{1}{c}{ Type of Food } & Pooled & 2007 & 2014 \\
\hline Beans & 6265.75 & 4976.52 & 7416.53 \\
Tofu and Tempe & $10,083.88$ & 6967.77 & $12,865.36$ \\
Meat & $72,140.50$ & $46,242.67$ & $95,257.18$ \\
Poultry & $24,625.09$ & $19,882.74$ & $28,858.17$ \\
Fish & $26,320.76$ & $18,926.58$ & $32,920.88$ \\
Milk & $31,913.15$ & $25,989.03$ & $37,201.08$ \\
\hline
\end{tabular}

Source: IFLS Data (Processed)

\section{Analysis Model}

\subsection{Quadratic Almost Ideal Demand System}

The quadratic almost ideal demand system (QUAIDS) approach was employed in order to be able to estimate the food demand behavior of the households. QUAIDS, developed by Banks et al., (1997), is a development of a previous model called AIDS pioneered by Deaton and Muellbauer (1980). In the QUAIDS, the Engel curve is considered nonlinear. It could change, depending on the quadratic expenditure term. Thus, an item could be a luxury item at some level of expenditure and change into a necessity item at another expenditure level. The equation could be formulated as follows:

$$
\begin{aligned}
w_{i}= & \alpha_{i}+\sum_{j=1}^{n} \gamma_{i j} \ln p_{j}+\beta_{i} \ln \left[\frac{m}{a(p)}\right]+ \\
& \frac{\lambda_{i}}{b(p)}\left\{\ln \left[\frac{m}{a(p)}\right]\right\}^{2}+\sum_{s=1}^{s} \delta_{i s} D_{s t}^{h}+u_{i t}^{h}
\end{aligned}
$$

where

$$
\begin{aligned}
& w_{i}: \begin{array}{l}
\text { expenditure share of all total food } \\
\text { expenditures }
\end{array} \\
& p_{i} \text { : price of food commodities i }
\end{aligned}
$$

$p_{j}$ : price of food commodities $\mathrm{j}$

$m$ : total of food expenditures

$D$ : set of demographic characteristics, namely, household size, household head's sex, household head's age, household head's education, distance to the traditional market, farming ownership status, urban/rural, Java/non-Java.

From that equation, the elasticity of demand could then be derived:

Expenditure Elasticity: $e_{i}=\frac{\mu_{i}}{w_{i}}+1$.

Uncompensated price elasticity/Marshallian:

$$
\mathrm{e}_{\mathrm{ij}}^{\mathrm{u}}=\frac{\mu}{\mathrm{w}_{\mathrm{i}}}-\delta_{\mathrm{ij}},
$$

Compensated price elasticity/Hicksian:

$$
e_{i j}^{c}=e_{i j}^{u}+w_{j} e_{i} \text {. }
$$

\subsection{Compensating Variation}

With regards to analyzing the effect of a price increase on household welfare, the compensating variation (CV) was applied. CV calculates the amount of money needed by households at the new price level to reach the same utility as they were at the initial price level. The CV can be calculated by using the second Taylor expansion, proposed by Friedman and Levinsohn (2002), in the following:

$$
\begin{aligned}
\ln C^{h} \approx & \sum_{i=1}^{n} w_{i}^{h} \Delta \ln P_{i}^{h}+ \\
& \frac{1}{2} \sum_{i=1}^{n} \sum_{i=j}^{n} w_{i}^{h} \varepsilon_{i j} \Delta \ln P_{i}^{h} \Delta \ln P_{j}^{h}
\end{aligned}
$$

The first part provides a maximum effect due to the price change and ignores the response of individual behavior, as well as the substitution effect on other cheaper commodities. The other part shows a dynamic response, not only seen from the food's price but also from another food's price to capture household behavior, with $\varepsilon_{i j}$ as the cross-price elasticity of Hicksian/compensated for i commodity over the price change 
of $\mathrm{j}$ commodity. The study then simulated the increases in food prices by $10 \%, 25 \%$, and $50 \%$. For the purpose of the analysis, the estimation was disaggregated by region (rural/urban), income group (20\% poorest household/20\% richest household), and island (Java/non-Java).

\section{RESULT AND DISCUSSION}

\section{Households' Consumption of High- Nutrient Foods from Their Own Farms}

The average share of consumption expenditure for each food type by the household groups is presented in Figure 1. The highest expenditure share of consumption of one's own farm products is on the fish commodity, for all the household classifications. Fish is considered a good source of protein that is cheaper in price than other commodities. It is also relatively easy to obtain because Indonesia is surrounded by the sea and ocean. The households that live outside Java have the highest level of fish consumption. For the non-Java households, especially those in East Indonesia such as Sulawesi, Maluku, and Papua, fish is a food that is consumed daily. Meanwhile, in Java, households prefer to consume more meat and poultry (KKP, 2018).

Less milk is consumed by rural and the poorest households, compared to urban and the richest households. In Indonesia, drinking milk is not a common habit, except when it is done by infants and children (Triratnawati, 2017). The price of milk is also relatively expensive so the low-income households cannot afford it. Furthermore, the lowest consumption share of their own products, for all households, is of tofu and tempe. Tofu and tempe are usually purchased at the market because their production involves several processes.

\section{QUAIDS Estimation Results}

The QUAIDS estimation results reveal that all the expenditure and quadratic expenditure terms are significant except for the fish commodity. It indicates that there is nonlinearity in the Engel curve in the consumption patterns. If the sign of the expenditure parameter is positive and that of the quadratic expenditure parameter is negative, it means that the goods concerned are included as normal goods at a lower level of expenditure and as inferior good at a higher level of expenditure. However, in the study, goods of that nature were not found. Nevertheless, tofu and tempe have the opposite pattern, whereas beans and meat are classified as normal goods at any level of expenditure. The results are presented in Table 3.

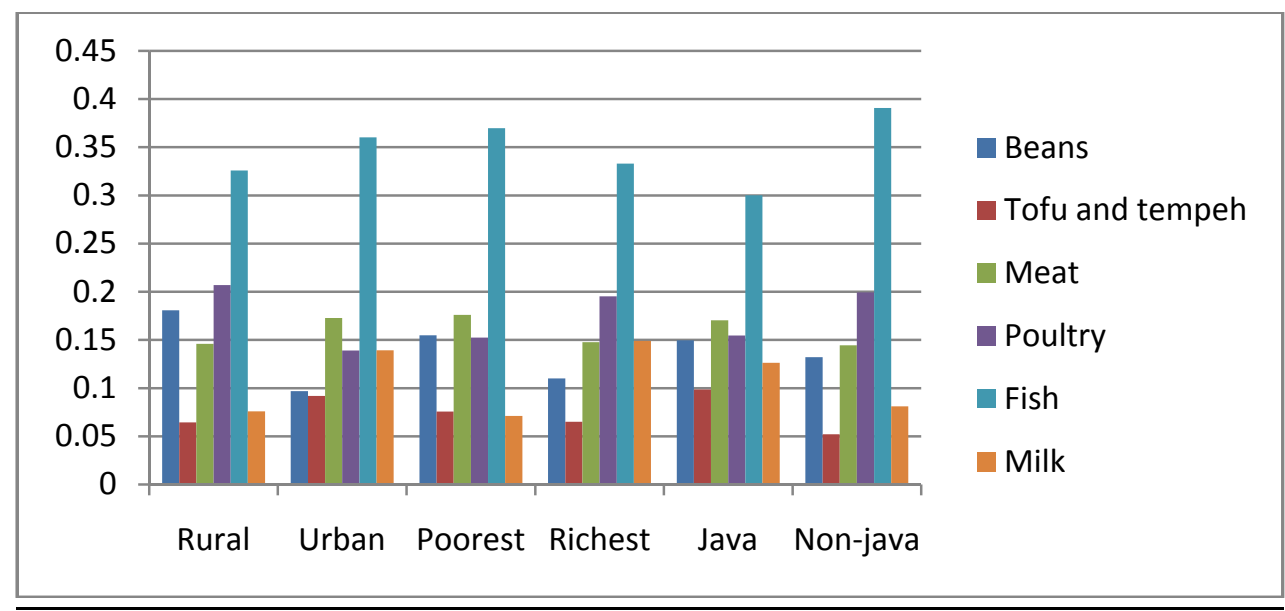

Source: Stata Output(Data Processed)

Figure 1. The Average Consumption of Protein-Source Food by Selected Household Groups 
Table 3. QUAIDS Estimation Results

\begin{tabular}{|c|c|c|c|c|c|c|}
\hline Groups & Beans & $\begin{array}{l}\text { Tofu and } \\
\text { Tempe }\end{array}$ & Meat & Poultry & Fish & Milk \\
\hline Constant & 0.4171 & -0.1542 & 1.7615 & -0.4393 & -0.2425 & -0.3425 \\
\hline \multicolumn{7}{|l|}{ Ln price } \\
\hline Beans & $0.1218^{* * *}$ & 0.0004 & $0.0633^{*}$ & $-0.1177^{* * *}$ & -0.0329 & $-0.0349 *$ \\
\hline Tofu and Tempe & 0.0004 & 0.0022 & 0.0150 & -0.0034 & $-0.0204 * *$ & 0.0062 \\
\hline Meat & $0.0633^{*}$ & 0.0150 & $0.2464 * * *$ & $-0.2022 * * *$ & -0.0356 & $-0.0868 * * *$ \\
\hline Poultry & $-0.1177 * * *$ & -0.0034 & $-0.2022 * * *$ & $0.2069 * * *$ & $0.0713^{* *}$ & $0.0451^{*}$ \\
\hline Fish & -0.0329 & -0.0204 & -0.0356 & $0.0713 * *$ & -0.0343 & $0.0519 * *$ \\
\hline Milk & $-0.0349 *$ & $0.0062 * *$ & $-0.0868 * * *$ & 0.0451 & $0.0519 * *$ & 0.0185 \\
\hline Ln expenditure & $0.1338^{* * *}$ & $-0.0048^{* * *}$ & $0.1974 * * *$ & $-0.1854 * * *$ & $-0.0831^{* * *}$ & $-0.0580 * * *$ \\
\hline Ln expenditure ${ }^{\wedge 2}$ & $0.0093^{* * *}$ & $0.0015 * *$ & $0.0039 * * *$ & $-0.0112 * * *$ & -0.0017 & $-0.0019 * *$ \\
\hline \multicolumn{7}{|c|}{ Demographic characteristics } \\
\hline $\begin{array}{l}\text { Distance to traditional } \\
\text { market }\end{array}$ & $-0.0010^{* * *}$ & -0.0001 & $0.0003^{* * *}$ & 0.0000 & $0.0006^{* * *}$ & 0.0001 \\
\hline Java & -0.0011 & $-0.0023 * * *$ & $-0.0043 * * *$ & 0.0008 & $0.0091^{* * *}$ & $-0.0022 * *$ \\
\hline Household size & -0.0007 & 0.0004 & 0.0005 & 0.0007 & -0.0008 & -0.0001 \\
\hline Sex (1 if male) & -0.0003 & -0.0001 & 0.0007 & 0.0023 & -0.0024 & -0.0002 \\
\hline Age & 0.0001 & 0.0000 & $-0.0001 * *$ & $-0.0001^{* *}$ & $0.0002^{* * *}$ & $-0.0001 * *$ \\
\hline Education & 0.0000 & 0.0001 & -0.0001 & $-0.0003 * *$ & $0.0007^{* * *}$ & $-0.0005 * * *$ \\
\hline Farms owning status & $-0.0092 * * *$ & $0.0025^{* *}$ & -0.0012 & $-0.0029 * *$ & $0.0072 * * *$ & $0.0036 * * *$ \\
\hline $\mathbf{N}$ & \multicolumn{6}{|c|}{3624} \\
\hline
\end{tabular}

Based on the demographic characteristics, the household head's age negatively affects meat, poultry, and milk consumption. Although it is not known whether the consumption of purchased food items is increasing or not, this might occur because older people tend to have more health risks so that the consumption of those commodities should be reduced. In terms of the educational level of the household head, the higher the level of education, the more fish is consumed. Based on the island, it turns out that consumption in Java is less than outside Java. This is possibly because of the decrease in farmland due to urbanization and industrialization in Java. Hence, the consumption of homegrown food is limited.

\section{Demand Elasticities}

\subsection{Price Elasticities}

There are two types of price elasticity, namely, own-price elasticity and cross-price elasticity.
Analysis of the price elasticity is used to capture how the household consumption of each commodity responds to price changes. The results show that all the signs are negative. The negative signs mean that all the protein-source food commodities are engaged with the law of demand. It means that if there is a price increase, the quantity demanded would decline. The results are presented in Table 4 for each household group.

Of the commodities, meat has the highest value of elasticity, and beans the lowest. This implies that even a small price change would lead to a substantial decline in the demand for meat. The high-value commodities are usually very sensitive to price changes. Meanwhile, beans are relatively cheap so that a price change would not lead to a significant decline in their consumption. However, in the poorest households, tofu and tempe are the most inelastic, which indicates that the poorest households tend 
Table 4. Own-price elasticity

\begin{tabular}{|c|c|c|c|c|c|}
\hline Food Group & Pooled & Rural & Urban & Poorest & Richest \\
\hline \multicolumn{6}{|c|}{ Uncompensated } \\
\hline Beans & $\begin{array}{c}-0.933 \\
(0.071)\end{array}$ & $\begin{array}{c}-0.847 \\
(0.098)\end{array}$ & $\begin{array}{l}-0.919 \\
(0.100)\end{array}$ & $\begin{array}{l}-1.191 \\
(0.150)\end{array}$ & $\begin{array}{l}-0.819 \\
(0.194)\end{array}$ \\
\hline Tofu and Tempe & $\begin{array}{l}-1.028 \\
(0.079)\end{array}$ & $\begin{array}{l}-1.010 \\
(0.098)\end{array}$ & $\begin{array}{l}-1.059 \\
(0.135)\end{array}$ & $\begin{array}{l}-0.960 \\
(0.163)\end{array}$ & $\begin{array}{c}-0.963 \\
(0.215)\end{array}$ \\
\hline Meat & $\begin{array}{l}-1.420 \\
(0.124)\end{array}$ & $\begin{array}{l}-1.052 \\
(0.169)\end{array}$ & $\begin{array}{l}-1.796 \\
(0.187)\end{array}$ & $\begin{array}{l}-1.477 \\
(0.296)\end{array}$ & $\begin{array}{l}-1.138 \\
(0.373)\end{array}$ \\
\hline Poultry & $\begin{array}{l}-1.106 \\
(0.109)\end{array}$ & $\begin{array}{l}-0.849 \\
(0.151)\end{array}$ & $\begin{array}{l}-1.148 \\
(0.160)\end{array}$ & $\begin{array}{l}-1.070 \\
(0.240)\end{array}$ & $\begin{array}{l}-1.734 \\
(0.319)\end{array}$ \\
\hline Fish & $\begin{array}{l}-1.160 \\
(0.048)\end{array}$ & $\begin{array}{l}-1.026 \\
(0.062)\end{array}$ & $\begin{array}{l}-1.264 \\
(0.078)\end{array}$ & $\begin{array}{l}-1.164 \\
(0.107)\end{array}$ & $\begin{array}{c}-0.995 \\
(0.153)\end{array}$ \\
\hline Milk & $\begin{array}{l}-1.058 \\
(0.079)\end{array}$ & $\begin{array}{l}-1.122 \\
(0.102)\end{array}$ & $\begin{array}{l}-1.048 \\
(0.123)\end{array}$ & $\begin{array}{l}-1.084 \\
(0.127)\end{array}$ & $\begin{array}{l}-0.898 \\
(0.330)\end{array}$ \\
\hline \multicolumn{6}{|c|}{ Compensated } \\
\hline Beans & $\begin{array}{c}-0.882 \\
(0.071)\end{array}$ & $\begin{array}{l}-0.824 \\
(0.098)\end{array}$ & $\begin{array}{l}-0.837 \\
(0.100)\end{array}$ & $\begin{array}{l}-1.141 \\
(0.151)\end{array}$ & $\begin{array}{c}-0.744 \\
(0.195)\end{array}$ \\
\hline Tofu and Tempe & $\begin{array}{l}-0.987 \\
(0.079)\end{array}$ & $\begin{array}{l}-0.963 \\
(0.098)\end{array}$ & $\begin{array}{l}-1.028 \\
(0.135)\end{array}$ & $\begin{array}{l}-0.917 \\
(0.162)\end{array}$ & $\begin{array}{c}-0.932 \\
(0.216)\end{array}$ \\
\hline Meat & $\begin{array}{l}-1.150 \\
(0.123)\end{array}$ & $\begin{array}{l}-0.811 \\
(0.167)\end{array}$ & $\begin{array}{l}-1.502 \\
(0.187)\end{array}$ & $\begin{array}{l}-1.196 \\
(0.293)\end{array}$ & $\begin{array}{l}-0.907 \\
(0.372)\end{array}$ \\
\hline Poultry & $\begin{array}{c}-0.864 \\
(0.108)\end{array}$ & $\begin{array}{l}-0.578 \\
(0.151)\end{array}$ & $\begin{array}{l}-0.939 \\
(0.160)\end{array}$ & $\begin{array}{c}-0.834 \\
(0.239)\end{array}$ & $\begin{array}{l}-1.470 \\
(0.317)\end{array}$ \\
\hline Fish & $\begin{array}{c}-0.848 \\
(0.048)\end{array}$ & $\begin{array}{l}-0.701 \\
(0.062)\end{array}$ & $\begin{array}{c}-0.953 \\
(0.077)\end{array}$ & $\begin{array}{c}-0.871 \\
(0.108)\end{array}$ & $\begin{array}{c}-0.647 \\
(0.153)\end{array}$ \\
\hline Milk & $\begin{array}{c}-0.976 \\
(0.079) \\
\end{array}$ & $\begin{array}{l}-1.030 \\
(0.102) \\
\end{array}$ & $\begin{array}{c}-0.975 \\
(0.123) \\
\end{array}$ & $\begin{array}{c}-0.987 \\
(0.127) \\
\end{array}$ & $\begin{array}{r}-0.848 \\
(0.330 \\
\end{array}$ \\
\hline $\mathbf{N}$ & & & 3.624 & & \\
\hline
\end{tabular}

Note: Standard error in parenthess

Source: Stata Output (data processed)

to consume tofu and tempe as sources of protein, rather than other commodities, when prices increase.

The elasticity value in the rural and poorest households is more inelastic than that in the urban and richest households, whether it is computed with the Marshallian or Hicksian method. These results indicate that the consumption of self-produced food has a role in securing the food needs of households that are vulnerable to economic shocks. It also implies that the poorest households tend to live in rural areas.

Cross-price elasticity estimates what the response of household consumption toward the price changes of other commodities is like (Table 5). All the positive signs for cross-price elasticity mean that among the commodity pairs there are substitutes. Meanwhile, any negative sign indicates the complementary relationship among commodities. The highest complementary effect is found between tofu and tempe together, and fish. Meanwhile, tofu and tempe together, and meat, have the highest substitution effect based on the pooled sample. Fish has quite a large substitution effect on other commodities such as beans, meat, and poultry, with an elasticity value range of 0.13-0.294. It implies that if the price of those commodities increases 
by $1 \%$, the demand for fish would increase by $0.13-0.294 \%$. In Indonesia, fish is the main source of animal protein because it is easy to find and the price is relatively cheap.

\subsection{Expenditure Elasticities}

Overall, the sign of the expenditure elasticity for protein-source food from people's own production is positive. It means that all the commodities are normal goods. Meat and poultry have higher values compared to the other commodities. Those commodities are a higher price than the other commodities, so it makes sense for them to have a higher value of expenditure elasticity (Wahyuni et al., 2016). However, the elasticity value of the other commodities such as beans, tofu and tempe, fish, and milk is lower than one, which indicates that those commodities are necessity goods. The detailed information is summarized in Table 6.

Table 5. Cross-Price Elasticity

\begin{tabular}{lcccccc}
\hline \multicolumn{1}{c}{ Food Group } & Beans & $\begin{array}{c}\text { Tofu and } \\
\text { tempe }\end{array}$ & Meat & Chicken & Fish & Milk \\
\hline \multicolumn{7}{c}{ Uncompensated } \\
Beans & \multicolumn{7}{c}{-0.058} & -0.017 & 0.387 & 0.206 & 0.053 \\
Tofu and tempe & -0.139 & & 0.598 & 0.174 & -0.194 & 0.056 \\
Meat & -0.184 & 0.204 & & -0.369 & 0.130 & -0.067 \\
Chicken & 0.164 & 0.007 & -0.264 & & -0.063 & -0.122 \\
Fish & 0.004 & -0.074 & 0.186 & 0.053 & & 0.077 \\
Milk & 0.002 & 0.020 & 0.051 & -0.088 & 0.294 & \\
& & Compensated & & & \\
Beans & -0.030 & 0.040 & 0.450 & 0.330 & 0.091 \\
Tofu and tempe & -0.063 & 0.058 & 0.682 & 0.267 & -0.012 & 0.112 \\
Meat & 0.058 & 0.336 & & -0.070 & 0.713 & 0.113 \\
Chicken & 0.360 & 0.114 & -0.045 & & 0.410 & 0.024 \\
Fish & 0.133 & -0.003 & 0.331 & 0.213 & & 0.173 \\
Milk & 0.112 & 0.080 & 0.174 & 0.049 & 0.561 & \\
\hline $\mathbf{N}$ & \multicolumn{7}{c}{$\mathbf{3 6 2 4}$} \\
\hline
\end{tabular}

Note: standard error in parentheses

Source: Stata output (data processed)

Table 6. Expenditure Elasticity

\begin{tabular}{lccccccc}
\hline \multicolumn{1}{c}{ Food Group } & Pooled & Rural & Urban & Poorest & Richest & Java & Non-Java \\
\hline Beans & 0.361 & 0.161 & 0.582 & 0.358 & 0.532 & 0.397 & 0.355 \\
& $(0.030)$ & $(0.044)$ & $(0.038)$ & $(0.069)$ & $(0.073)$ & $(0.040)$ & $(0.041)$ \\
Tofu and Tempe & 0.533 & 0.614 & 0.397 & 0.556 & 0.403 & 0.492 & 0.573 \\
& $(0.043)$ & $(0.054)$ & $(0.066)$ & $(0.093)$ & $(0.105)$ & $(0.064)$ & $(0.051)$ \\
Meat & 1.704 & 1.522 & 1.852 & 1.774 & 1.457 & 1.764 & 1.570 \\
& $(0.029)$ & $(0.039)$ & $(0.041)$ & $(0.068)$ & $(0.078)$ & $(0.038)$ & $(0.040)$ \\
Poultry & 1.386 & 1.544 & 1.192 & 1.348 & 1.506 & 1.317 & 1.459 \\
& $(0.028)$ & $(0.039)$ & $(0.036)$ & $(0.061)$ & $(0.077)$ & $(0.035)$ & $(0.041)$ \\
Fish & 0.914 & 0.953 & 0.911 & 0.856 & 1.017 & 0.915 & 0.917 \\
& $(0.018)$ & $(0.024)$ & $(0.026)$ & $(0.039)$ & $(0.045)$ & $(0.023)$ & $(0.027)$ \\
Milk & 0.780 & 0.875 & 0.692 & 0.913 & 0.481 & 0.782 & 0.829 \\
& $(0.038)$ & $(0.045)$ & $(0.060)$ & $(0.071)$ & $(0.114)$ & $(0.054)$ & $(0.049)$ \\
\hline
\end{tabular}

Note: standard error in parentheses

Source: Stata Output (Data Processed) 
The expenditure elasticity for food items is higher in rural households compared to that in urban households. This result is in line Mittal (2010), indicating that rural households have a greater budget for consuming more of the food that they produce. A similar pattern is also found for the following: based on the income group, the poorest households have a higher elasticity of expenditure. Generally, for all the household groups, two types of plant-protein sourced food, namely, beans and tofu and tempe, are more inelastic compared to animal-protein sourced food. It implies that the household consumption of those commodities, from the households' own production is relatively stable and insensitive to expenditure changes. In fact, the consumption of animal protein in Indonesia is still not very high.

\section{Welfare Change Analysis}

There are three scenarios for evaluating household welfare changes due to increases in food prices. Scenario 1 is a $10 \%$ price increase, Scenario 2 is a $25 \%$ price increase, and Scenario 3 is a $50 \%$ price increase. It is assumed that the rising prices are only consumer prices, not producer prices. Generally, the food price spike causes welfare losses for all the household groups. It can be seen from the resulting negative sign of the compensating variation value (Table 7). A higher price increase is followed by a higher welfare loss. However, the magnitude of the $\mathrm{CV}$ differs among household groups. According to Friedman and Levinsohn (2002), the difference in the effect between a price increase and a change in the level of a household's welfare is due to the different regions, products, and household characteristics. Households that have a resource which helps them to cope with economic shocks would be more secure than households which do not.
Table 7. Compensating Variation

\begin{tabular}{lccc}
\hline $\begin{array}{l}\text { Percentage of } \\
\text { Price Increase }\end{array}$ & $\mathbf{1 0 \%}$ & $\mathbf{2 5 \%}$ & $\mathbf{5 0 \%}$ \\
\hline Pooled & $\mathbf{- 5 . 0 7 \%}$ & $\mathbf{- 1 0 . 6 7 \%}$ & $\mathbf{- 1 6 . 2 9 \%}$ \\
Poorest & $-4.44 \%$ & $-8.99 \%$ & $-12.74 \%$ \\
Richest & $-4.81 \%$ & $-9.96 \%$ & $-14.75 \%$ \\
Rural & $-5.59 \%$ & $-12.00 \%$ & $-19.01 \%$ \\
Urban & $-4.08 \%$ & $-8.06 \%$ & $-10.78 \%$ \\
Java & $-5.10 \%$ & $-10.74 \%$ & $-16.37 \%$ \\
Non-Java & $-4.84 \%$ & $-10.06 \%$ & $-14.97 \%$ \\
\hline
\end{tabular}

Source: Stata Output (Data Processed)

The average welfare loss experienced by households is $10.67 \%$ and $16.29 \%$ due to price increases of $25 \%$ and $50 \%$, respectively. The poorest households experience a smaller welfare loss compared to the richest households. Allo et al. (2018) states that when food prices increase, the low-income groups would immediately buy food. Meanwhile, the medium-high income groups would slowly respond to the price increase. However, rural households are found to have the greatest welfare loss, which is not as expected because they are assumed to have more resources with which to cope with economic shocks as has been shown in the results of previous studies (Allo et al., 2018; Vu \& Glewwe, 2015). However, that particular result is in line with Weber (2015) in India. It occurred probably because the study concerned here did not include producers' price changes. Rural households act as two agents in the economy, as consumers and producers. Thus, if the price increases, they could choose whether to consume their own farm products or sell them to get more benefits (Akbari et al., 2013). Based on the island, households on Java have a greater decline in their well-being compared to other households. This result is related to the quick flow of information, goods, and services in Java, which cause a rapid response to and from the households. Thus, households in Java would experience a greater and faster welfare loss. 


\section{CONCLUSION}

The objective of the study was to analyze the demand for high-nutrient food items and to evaluate the welfare effect on Indonesian households due to price increases to them. Using a large sample of data from the Indonesian Family Life Survey (IFLS), the study employed the quadratic almost ideal demand system (QUAIDS) to identify the demand pattern and applied compensating variation (CV) to understand the impact of soaring food prices on welfare changes.

The results of the study reveal that the fish commodity has the highest share of consumption by all the household groups who have their own farm products. This implies Indonesian people are slowly consuming more high-protein foods. With regards to price elasticity, all the food commodities have a negative sign that indicates that all the food groups are subject to the law of demand. The own-price elasticity is more inelastic for the poorest and rural households, which indicates that there is a role for homegrown farm products to help secure vulnerable households due to price volatility. Based on expenditure elasticity, the results show that all the signs are positive, which means that all the food items are normal goods. The magnitude of expenditure elasticity is higher in rural households than in urban households. This suggests that rural households have a higher budget for consuming more of the food they produce. A similar pattern is also found based on the income group, with the poorest households having a higher elasticity of expenditure.

Furthermore, the analysis of the compensating variation denotes that when prices increase, all the household groups would experience a welfare loss. A higher price increase would cause a greater decline in household well-being; however the poorest households experience less of a welfare loss than the richest households. It indicates that, for the low-income households, their own farm products could overcome the economic shock. The results also show that households that are in rural areas and in Java have greater welfare losses than other households.

\section{IMPLICATION/LIMITATION AND SUGGESTIONS}

The poorest households experience less of a welfare loss than the richest households. This indicates that, for low-income households, their own farm products could overcome an economic shock. Therefore, the government should support the small-scale farming undertaken by households through strategic policies such as giving assistance and training in how to manage a small farm. The results also show that households in rural areas and in Java have greater welfare losses than other households. Therefore, the government should consider demographic and regional characteristics when applying its food policies.

The study has several limitations, which are that it assumed prices changed only for consumers, and did not include price changes on the producers' side, despite the fact that households which have their own farming business are not only consumers but also producers, so that price changes on the producers' side would also influence the pattern of high-protein food's consumption in households in Indonesia. Therefore, in future studies, one could consider including price changes on the producers' side too.

\section{REFERENCES}

Abdulai, A. (2002). Household Demand for Food in Switzerland. A Quadratic Almost Ideal Demand System. Swiss Society of Economics and Statistics, 138(I), 1-18.

Aftab, S., Yaseen, M. R., \& Anwar, S. (2017). 
Impact of rising food prices on consumer welfare in the most populous countries of South Asia International Journal of Social Economics Article information: International Journal of Social Economics, 44(8), 1062-1077. https://doi.org/10.1108/IJSE01-2016-0016

Agbola, F. W. (2000). Estimating The Demand For Food And Non-Food Items Using An Almost Ideal Demand System Modelling Approach. In the 44th Annual Conference of the Australian Agricultural and Resource Economics Society, Inc., 1-14. Sidney.

Akbari, A., Ziaei, M. B., \& Ghahremanzadeh, M. (2013). Welfare Impacts of Soaring Food Prices on Iranian Urban Households: Evidence from survey data. International Journal of Business and Development Studies, 5(1), 23-38.

Allo, A. G., Satriawan, E., \& Arsyad, L. (2018). THE IMPACT OF RISING FOOD PRICES ON FARMERS ' WELFARE. Journal of Indonesian Economy and Business, 33(3), 193-215.

Attanasio, O., Di Maro, V., Lechene, V., \& Phillips, D. (2013). Welfare consequences of food prices increases: Evidence from rural Mexico. Journal of Development Economics, 104, 136-151. https://doi.org/10.1016/j.jdeveco.2013.03.00 9

Badan Pusat Statistik. (2016). Inflasi Indonesia Menurut Kelompok Pengeluaran 20062015.

Banks, J., Blundell, R., \& Lewbel, A. (1997). Quadratic Engel Curves and Consumer Demand James. The Review of Economics and Statistics, 79(4), 527-539. Retrieved from http://links.jstor.org/sici?sici=00346535\%28199711\%2979\%3A4\%3C527\%3A QECACD\%3E2.0.CO\%3B2-Z

Deaton, A., \& Muellbauer, J. (1980). An Almost Ideal Demand System. American Economic Association, 70(3), 312-326.

Diehl, J. A., Oviatt, K., Chandra, A. J., \& Kaur, H. (2019). Household Food Consumption Patterns and Food Security among Low-
Income Migrant Urban Farmers in Delhi , Jakarta, and Quito. Sustainability, 11(1378), 1-18. https://doi.org/10.3390/su11051378

F.R, R., \& Rahji, M. A. . (2014). A Comparative Analysis of Diet Quality in Urban dan Rural Household in Ibadan Zone of Oyo State, Nigeria. Agrosearch, 14(2), 90-102.

Fabiosa, J. F., \& Jensen, H. H. (2002). Microeconomic Adjustments of Households to Macroeconomic Shocks: Household Level Welfare Impacts of the Indonesian Economic Crisis. AAEA Annual Meeting in Long Beach, California, 1-18.

FAO. (2017). Country Fact Sheet on Food and Agriculture Policy Trends.

Frandhika, A. R. (2015). Dampak kenaikan harga daging sapi terhadap perilaku konsumen. Universitas Padjajaran.

Friedman, J., \& Levinsohn, J. (2002). The Distributional Impacts of Indonesia's Financial Crisis on Household Welfare : A “ Rapid Response " Methodology. The World Bank Economic Review, 16(3), 397-423. https://doi.org/10.1093/wber/lhf001

Haq, Z. U. L., Nazli, H., Meilke, K., Ishaq, M., Khattak, A., Hashmi, A. H., \& Rehman, F. U. R. (2011). Food demand patterns in pakistani punjab. Sarhad Journal of Agriculture, 27(2), 305-311.

Kearney, J. (2010). Food consumption trends and drivers. Philosophical Transactions of the Royal Society B: Biological Sciences, 365(1554), 2793-2807.

https://doi.org/10.1098/rstb.2010.0149

Kementerian Perdagangan. (2016). Buletin Gejolak Harga Daging Ayam (Vol. 1).

KKP. (2018). Permasalahan Konsumsi dan Manfaat Ikan.

Korir, L., Rizov, M., \& Ruto, E. (2018). Analysis of household food demand and its implications on food security in Kenya: an application of QUAIDS model (No. (No. 2111-2018-4123).).

Kumar, P., Kumar, A., Parappurathu, S., \& Raju, S. S. (2011). Estimation of Demand 
Elasticity for Food Commodities in India. Agricultural Economics Research Review, 24(June), 1-14. Retrieved from

http://www.indianjournals.com/ijor.aspx?tar get $=$ ijor:aerr \&volume $=24 \&$ issue $=1 \&$ article $=001$

Le, C. Q. (2008). An Empirical Study of Food Demand in Vietnam. Asean Economic Bulletin, 25(3), AE25-3C. https://doi.org/10.1355/AE25-3C

Me-Nsope, N. M., \& Staatz, J. M. (2016). Household-Level Evidence of Cereals Demand and the Welfare Implications of Cereals Price Shocks in Rural and Urban Mali. Retrieved from http://fsg.afre.msu.edu/srai2/WP2016_01_ MeNsope_Staatz_Household_paper_AAAE _RESUBMISSION.pdf

Mittal, S. (2010). Application of The QUAIDS Model to the Food Sector in India. Journal of Quantitative Economics, 8(1).

Okrent, A. M., \& Alston, J. M. (2011). Demand for Food in the United States: A Review of Literature, Evaluation of Previous Estimates, and Presentation of New Estimates of Demand. Giannini Foundation Monograph 48, (April), 125.

Pangaribowo, E. H., \& Tsegai, D. (2011). Food demand analysis of Indonesian households with particular attention to the poorest. ZEF-Discussion Papers on Development Policy, (151).
Sabo, B. B., Isah, S. D., Chamo, A. M., \& Rabiu, M. A., (2018). Role of Smallholder Farmers in Nigeria's Food Security Role of Smallholder Farmers in Nigeria's Food Security. Journal of Agricultural Science, 7(1), 1-5.

Triratnawati, A. (2017). Makna susu bagi konsumen mahasiswa di kafe susu di Yogyakarta : antara gizi dan gengsi. Jurnal Gizi Klinik Indonesia, 14(1), 27-35.

Vu, L., \& Glewwe, P. (2015). Impacts of Rising Food Prices on Poverty and Welfare in Vietnam Poverty of Rising Food Prices on and Welfare in Vietnam. Journal of Agricultural and Resources Economics, 36(1), 1427.

Wahyuni, D., Purnastuti, L., \& Mustofa. (2016). Analisis Elastisitas Tiga Bahan Pangan Sumber Protein Hewani di Indonesia. Jurnal Economia, 12(1), 43-53.

Wardhani, A. T. (2017). The Impact of Own Produced Consumption on Rural Households' Consumption Patterns. Jurnal Ekonomi Dan Kebijakan Publik, 8(1), 13-25.

Weber, R. (2015). Welfare Impacts of Rising Food Prices: Evidence from India. International Conference of Agricultural Economists: Agriculture In An Interconnected World.

Widarjono, A. (2012). Food and nutrient demand in Indonesia (Oklahoma State University). Retrieved from http://search.proquest.com/docview/131860 0335? accountid=13771 